\title{
A process efficiency assessment of serum protein removal from milk using ceramic graded permeability microfiltration membrane
}

\author{
D. Tremblay-Marchand, ${ }^{*}$ A. Doyen, ${ }^{*}$ M. Britten, ${ }^{*} \dagger$ and Y. Pouliot ${ }^{* 1}$ \\ *STELA Dairy Research Center, Institute of Nutrition and Functional Foods (INAF), Department of Food Sciences, Université Laval, \\ Québec, QC, Canada, G1V 0A6 \\ †Food Research and Development Centre (FRDC), Agriculture and Agri-Food Canada, St-Hyacinthe, QC, Canada, J2S 8E3
}

\begin{abstract}
Microfiltration (MF) is a well-known process that can be used in the dairy industry to separate caseins from serum proteins (SP) in skim milk using membranes with a pore diameter of $0.1 \mu \mathrm{m}$. Graded permeability ceramic membranes have been studied widely as means of improving milk fractionation by overcoming problems encountered with other MF membranes. The ideal operating parameters for process efficiency in terms of membrane selectivity, permeate flux, casein loss, SP transmission, energy consumption, and dilution with water remain to be determined for this membrane. Our objective was to evaluate the effects of transmembrane pressure (TMP), volumetric concentration factor (VCF), and diafiltration on overall process efficiency. Skim milk was processed using a pilot-scale MF system equipped with $0.72-\mathrm{m}^{2}$ graded permeability membranes with a pore size of $0.1 \mu \mathrm{m}$. In the first experiment, in full recycle mode, TMP was set at 124, 152, 179, or $207 \mathrm{kPa}$ by adjusting the permeate pressure at the outlet. Whereas TMP had no significant effect on permeate and retentate composition, $152 \mathrm{kPa}$ was found to be optimal for SP removal during concentration and concentration or diafiltration experiments. When VCF was increased to $3 \times$, SP rejection coefficient increased along with energy consumption and total casein loss, whereas SP removal rate decreased. Diafiltering twice allowed an increase in total SP removal but resulted in a substantial increase in energy consumption and casein loss. It also reduced the SP removal rate by diluting permeate. The membrane surface area required for producing cheese milk by blending whole milk, cream, and MF retentate (at different VCF) was estimated for different cheese milk casein concentrations. For a given casein concentration, the same quantity of permeate and SP would be produced, but less membrane surface area would be needed at a lower retentate VCF. Mi-
\end{abstract}

Received January 19, 2016.

Accepted March 21, 2016.

${ }^{1}$ Corresponding author: yves.pouliot@fsaa.ulaval.ca crofiltration has great potential as a process of adding value to conventional cheesemaking processes, but its cost-effectiveness at a large scale remains to be demonstrated.

Key words: microfiltration, graded permeability membrane, process efficiency, energy consumption, mass balance

\section{INTRODUCTION}

Microfiltration (MF) is a pressure-driven, membranebased process used to concentrate particles in the 0.1 to $10 \mu \mathrm{m}$ size range and to separate them from the suspending liquid (Saboya and Maubois, 2000). The first major application of MF in the dairy industry was for the removal of bacteria from milk using a membrane having a pore size of $1.4 \mu \mathrm{m}$ (Trouvé et al., 1991). A pore size of $0.1 \mu \mathrm{m}$ allows the separation of casein micelles from SP of skim milk (Saboya and Maubois, 2000). The casein-enriched retentate thus obtained can be used to standardize cheese milk, whereas the clear, fat-free, and sterile serum protein (SP)-enriched permeate has a composition similar to cheese whey. Serum proteins contained in the MF permeate are functionally and nutritionally superior to SP from cheese whey, which gives it an excellent potential for production of SP concentrates or isolates (Saboya and Maubois, 2000). This process also allows the production of micellar casein concentrate (MCC), a novel dairy ingredient obtained by diafiltering the casein-enriched retentate. This highprotein ingredient can be used in the formulation of different products due to its nutritive and functional value, as well as its stability during processing.

Ceramic is a popular choice of membrane material for MF applications due to its resistance to back-pressure and steam sterilization, its narrow pore size distribution, and the high permeate flux obtainable (Zulewska et al., 2009; Fernández García and Riera Rodríguez, 2015). First-generation ceramic membranes fouled quickly, decreasing selectivity, permeate flux, and overall performance (Saboya and Maubois, 2000). To overcome this problem, Sandblom (1978) developed the uniform transmembrane pressure (UTP) system, 
whereas Alfa Laval (Kolding, Denmark) improved and patented this process a few years later (Holm et al., 1990). In this system, MF permeate is recirculated in a loop parallel to the retentate flow, which allows a lower and more UTP from the retentate inlet to the outlet and reduces membrane fouling. Although the UTP system performed well, it was not adopted widely, due mainly to high operating costs associated with the permeate recirculation pump and the difficulty of adjusting pressure drops on the permeate and retentate sides (Hu and Dickson, 2015). In recent years, several attempts were made to achieve the benefits of UTP system, but without the permeate recirculation pump (Saboya and Maubois, 2000). One promising alternative to UTP systems is the graded permeability (GP) ceramic membrane (Membralox GP, Pall Corp., East Hills, NY). With GP membranes, uniform permeate flux is obtained by incorporating a variation in the porosity of the membrane support along the length of the filtration element (Garcera and Toujas, 2002). This allows MF with less energy expenditure and simpler operation than with UTP systems (Hu and Dickson, 2015).

A study comparing UTP and GP systems for separating SP from skim milk has shown that UTP allows greater passage of SP, whereas permeate flux is greater through the GP membrane (Zulewska et al., 2009). Spiral-wound polymeric membrane $(0.3 \mu \mathrm{m}$ pore size $)$ and Isoflux (TAMI, Nyons, France) ceramic membrane have been found less effective than UTP or GP systems (Zulewska et al., 2009; Adams and Barbano, 2013). Previous work by Zulewska and Barbano (2014) evaluated the effect of diafiltration (DF) on the efficiency of SP removal during MF of skim milk. Most studies of the performance of GP membranes have been conducted under feed-and-bleed conditions, which allow continuous production of retentate with a volumetric concentration factor (VCF) of $3 \times$ by adjusting permeate and retentate removal rates during the process. Whereas this process is used widely by dairy processors, it is prone to fluctuating operating pressures and Starling flow (permeate backflow into the retentate), which increases membrane fouling and reduces the effective filtration surface area (Zulewska et al., 2009).

Efficiency can be defined as the link between results obtained and the amount of resources used. For a dairy processor, the ideal MF process would yield retentate sufficiently enriched in casein to be useful for standardizing cheese milk, plus permeate containing high-value $\mathrm{SP}$ and as little casein as possible would require low energy input and minimal dilution with water and would have a high permeate flux (Noble and Agrawal, 2005). To maximize process efficiency, MF should be performed at a transmembrane pressure (TMP) at or below the critical flux defined as the mean flux at which a fouling layer begins to accumulate on the membrane (Bacchin, 2004). Raising the TMP above the critical flux increases the thickness of the fouling layer and decreases SP transmission (Gésan-Guiziou et al., 1999). Zulewska and Barbano (2014) determined that the critical flux of skim milk in a continuous feedand-bleed process with a VCF of $3 \times$ using a $0.1-\mu \mathrm{m}$ GP membrane was $64 \mathrm{~L} / \mathrm{m}^{2}$ per hour. Under the same conditions, the maximal flux attainable (limiting flux) was estimated at $96 \mathrm{~L} / \mathrm{m}^{2}$ per hour. Sustainable flux is defined as the flux that can be maintained for a long time with minimal fouling, and is usually in between the critical and limiting fluxes (Hurt et al., 2015a). It was determined that this flux can be achieved at a TMP of $150 \mathrm{kPa}$ regardless of the target protein concentration or membrane channel diameter. During MF of skim milk at a VCF of $3 \times$, and using a 4-mm channel diameter GP membrane, this flux corresponds to 80 to $85 \%$ of the limiting flux $\left(77-82 \mathrm{~L} / \mathrm{m}^{2}\right.$ per hour; Hurt et al., 2015a). Other parameters, such as pressure drop, cross-flow velocity, operating temperature, membrane properties, type of pasteurization, feed concentration, and DF, have an influence on the efficiency of skim milk MF (Bacchin et al., 2006; Hu and Dickson, 2015).

Whereas the effects of channel diameter (Hurt et al., 2015a) and retentate protein concentration (Hurt et al., 2015b) on the limiting flux and the SP removal using GP membrane have been studied, no study has focused on attempts to perform batch filtrations at constant operating pressures. This would provide the truest assessment of GP membrane performance at different VCF and TMP. To the best of our knowledge, little attention has been devoted to processing efficiency in terms of overall mass balance under different conditions and, more importantly, to the in situ energy requirements of those conditions. The goal of our study was to characterize the performance of a $0.1-\mu \mathrm{m}$ pore size GP membrane at different TMP and different VCF and to evaluate the effect of DF on the separation of SP from skim milk and on overall process efficiency.

\section{MATERIALS AND METHODS}

\section{Skim Milk Preparation}

Whole raw bovine milk was purchased from the bulk of a local dairy. Raw milk was heated to $45^{\circ} \mathrm{C}$ in a heat exchanger then separated using a centrifugal cream separator (model MP1254, Westfalia, Oelde, Germany). The cream was discarded and the skim milk $(<0.05 \%$ fat) was HTST-pasteurized in a heat exchanger (APV, Goldsboro, NC) at $74^{\circ} \mathrm{C}$ for $16 \mathrm{~s}$. The pasteurized skim milk was cooled to $4^{\circ} \mathrm{C}$ and stored at $4^{\circ} \mathrm{C}$ in a refrig- 
erated tank (model 180, DeLaval, Peterborough, ON, Canada) until the experiments.

\section{MF System}

The MF system (model 393, Tetra Pak Filtration Systems, Champlin, MN) schematized in Figure 1 was equipped with $0.1-\mu \mathrm{m}$ pore diameter Membralox ceramic GP membrane (modelr EP1940, Pall Corp.) with a surface area of $0.72 \mathrm{~m}^{2}$. The tubular membranes had a configuration with 3 tubes, 19 channels each, with a channel diameter of $4 \mathrm{~mm}$, in a stainless steel module that was mounted vertically in the system. Retentate inlet was located at the bottom of the membrane module and permeate was removed from the top of the module. Two feed pumps, one for nanofiltration or reverse osmosis (modelr H-25, Wanner Engineering Inc., Minneapolis, MN) and one for MF or UF (modelr LKHP-10, Alfa Laval), worked simultaneously, and one recirculation pump (modelr LKHP-10, Alfa Laval) was used. Electromagnetic flow meters (modelr SM2001, IFM Electronic, Malvern, PA) were used to measure feed, retentate, and permeate flow rates. Pressure transmitter (modelr PF265x, IFM Electronic) locations are marked as retentate pressure at the inlet (Rpi), retentate pressure at the outlet (Rpo), and permeate pressure at the outlet (Ppo) in Figure 1. A heat exchanger on the feed loop and a thermocouple probe (modelr FD02, Pyromation, Fort Wayne, IN) provided temperature control.

\section{Preliminary Operations}

Prior to processing, the milk was maintained at $50^{\circ} \mathrm{C}$ for $1 \mathrm{~h}$ in a stainless steel intermediary tank (modelr DSC12336, Qualtech, Québec, QC, Canada) to establish protein and mineral balance between the soluble and colloidal phases (Jimenez-Lopez et al., 2008). The membrane storage solution $(0.1 \% \mathrm{vol} / \mathrm{vol}$ Membra-Stor 710, Sani-Marc, Victoriaville, QC, Canada) was flushed

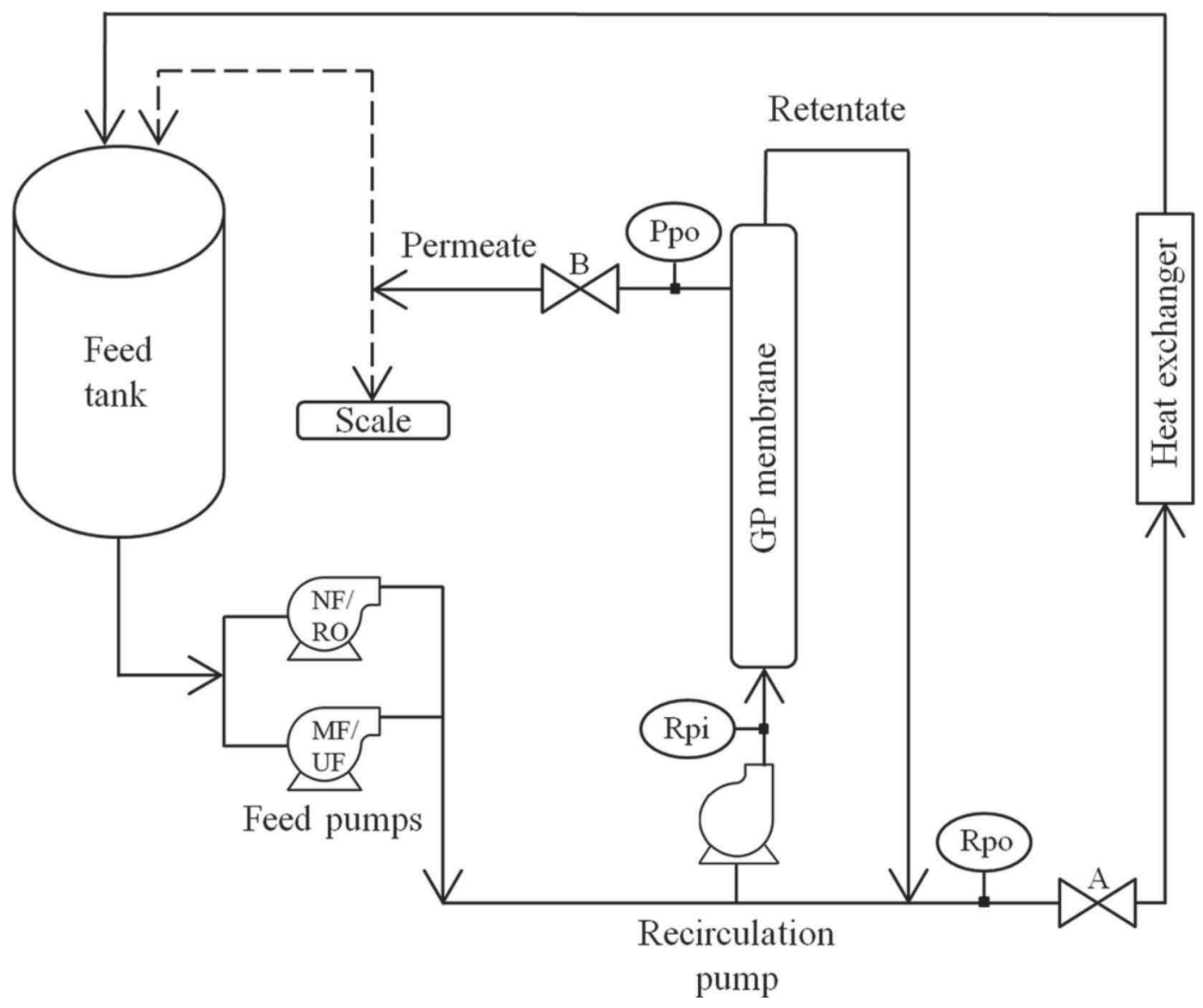

Figure 1. Schematic of the microfiltration system. Rpi = retentate pressure at the inlet; Rpo $=$ retentate pressure at the outlet; Ppo $=$ permeate pressure at the outlet; $\mathrm{NF} / \mathrm{RO}=$ feed pump for high operating pressure (nanofiltration and reverse osmosis); $\mathrm{MF} / \mathrm{UF}=\mathrm{feed}$ pump for low operating pressure (microfiltration and ultrafiltration); $\mathrm{A}=$ feed valve; $\mathrm{B}=$ permeate valve. Permeate was either removed from the system and weighed on a scale during concentration or recirculated in the feed tank during the full recycle operation; Retentate was always recirculated to the feed tank. 
out of the system with tap water at $25^{\circ} \mathrm{C}$ until the $\mathrm{pH}$ was neutral on the permeate and retentate sides. The MF system was then heated gradually $\left(<10^{\circ} \mathrm{C} / \mathrm{min}\right)$ to $50^{\circ} \mathrm{C}$ and a caustic solution $(1.95 \% \mathrm{vol} / \mathrm{vol}$ MembraChlor 310, Sani-Marc) was added to the system and recirculated for $25 \mathrm{~min}$. After cleaning, the caustic solution was flushed out of the system using tap water at $50^{\circ} \mathrm{C}$ until the $\mathrm{pH}$ of the flush water was neutral. The clean water flux was measured with tap water at $50^{\circ} \mathrm{C}$ at a TMP of $172 \mathrm{kPa}$, with the feed valve closed, and only the MF or UF feed pump on.

\section{Experimental Design}

Three different experiments were performed in duplicate. For each experiment, one batch of milk was divided into 2 equal parts. Optimal pressure conditions were determined during an experiment conducted in full recycle mode with nonconcentrated skim milk. The pressure thus determined was used in the concentration experiment until a VCF of $3 \times$ was obtained. Finally, the concentration/DF condition was the same as described previously except that the initial VCF $3 \times$ retentate was diluted 1:2 with tap water and then reconcentrated to a VCF of $3 \times$. This DF procedure was performed twice.

\section{Determination of the Optimal TMP for SP Removal}

Each replicate began with $80 \mathrm{~kg}$ of skim milk to flush the tap water out of the MF system with the permeate outlet closed to prevent membrane fouling (Cheryan, 1998). After the flush, the MF system was shut down and the remaining milk was flushed with manual valves. An estimated $30 \mathrm{~kg}$ of skim milk could not be flushed from the system. The feed tank was then filled with $100 \mathrm{~kg}$ of skim milk for the actual test. The system was started up and the pressure was adjusted to the lowest setting in full recycle mode. For each pressure level, Rpi and Rpo were kept constant at 310 and 103 $\mathrm{kPa}$, respectively, thus providing a pressure drop (Rpi $-\mathrm{Rpo}$ ) of $207 \mathrm{kPa}$, which is optimal for GP membrane and allows a cross-flow velocity of about $7 \mathrm{~m} / \mathrm{s}$ (Adams et al., 2015). Thus, the only factor affecting the TMP was the Ppo, which was $83,55,28$, and $0 \mathrm{kPa}$ (pressure levels $1,2,3$, and 4 , respectively); average TMP were then 124, 152, 179, and $207 \mathrm{kPa}$, respectively. The Ppo was always lower than Rpo to prevent Starling flow.

Skim milk was processed at $50^{\circ} \mathrm{C}$. Each pressure level was maintained for $45 \mathrm{~min}$ and the permeate flux was measured at $0,15,30$, and $45 \mathrm{~min}$. The pressure was allowed to stabilize for 15 min between TMP adjustments, and the milk was then recirculated for another $45 \mathrm{~min}$. Permeate and retentate samples were taken after 30 min of recirculation at each pressure level. Skim milk was sampled directly from the feed tank at the beginning of the experiment. All samples were cooled to $4^{\circ} \mathrm{C}$ and frozen at $-18^{\circ} \mathrm{C}$ until analysis.

\section{Skim Milk Concentration}

Following the full recycle experiment, it was determined that a TMP of $152 \mathrm{kPa}$ was optimal for SP removal and was therefore chosen for the skim milk concentration experiments. This TMP value was similar to that obtained by Hurt et al. (2015a) and corresponded to the sustainable flux estimated for skim milk MF using GP membranes. All concentration steps were carried out in batch mode to keep operating pressures as steady as possible during the process. For each replicate, water was flushed according to the same procedure as described for the full recycle experiment. After the flush, $230 \mathrm{~kg}$ of skim milk were added to the feed tank, bringing the total quantity of skim milk in the system to $260 \mathrm{~kg}$. The MF system was started in full recycle mode until pressure conditions were established. Permeate was then removed from the system and weighed during the entire run for real-time VCF measurements. Permeate flux was measured every 15 min. Skim milk was sampled in the feed tank at the beginning of the experiment (before concentration). Permeate and retentate samples were taken at VCF of $1.5,2,2.5$, and $3 \times$. All samples were cooled to $4^{\circ} \mathrm{C}$ and frozen at $-18^{\circ} \mathrm{C}$ until analysis.

\section{Skim Milk Concentration and DF}

Flushing and starting procedures, as well as operating pressures, were as described for the concentration experiment. For each replicate, skim milk was concentrated to a VCF of $3 \times$, followed by 2 batch DF. For each $\mathrm{DF}, 173 \mathrm{~kg}$ of tap water were used, which is equivalent to the permeate weight removed during concentration. After adding the water, the MF system was put in full recycle mode for $5 \mathrm{~min}$ to blend the retentate, permeate, and water. Permeate was then withdrawn again to reach a VCF of $3 \times$. Permeate flux was measured every 15 min and VCF was monitored in real-time.

Skim milk was sampled at the beginning of the experiment directly from the feed tank. Permeate and retentate samples were taken at a VCF of $3 \times$ after initial concentration, and at the end of each DF step. All samples were cooled to $4^{\circ} \mathrm{C}$ and frozen at $-18^{\circ} \mathrm{C}$ until analysis.

\section{Cleaning Procedure}

After each MF condition, the permeate outlet was closed and the system was flushed with tap water at 
$50^{\circ} \mathrm{C}$ until the retentate side water was completely clear. The fouled membrane flux was then measured using the same parameters as the initial clean water flux measurement. Thereafter, the system was sanitized with $1.95 \%$ (vol/vol) Membra-Chlor 310 solution (SaniMarc) until the chlorine level reached $0.02 \%$ vol/vol. The caustic solution $\left(50^{\circ} \mathrm{C}\right)$ was recirculated for $30 \mathrm{~min}$ and then flushed out with tap water at $50^{\circ} \mathrm{C}$ until the flush water $\mathrm{pH}$ was neutral. Ultrasil 76 (Ecolab Inc., St Paul, MN) was added $(0.3 \% \mathrm{vol} / \mathrm{vol})$ to the feed tank and recirculated for $30 \mathrm{~min}$ at $50^{\circ} \mathrm{C}$. The acidic solution was flushed out with tap water at $50^{\circ} \mathrm{C}$ until the flush water $\mathrm{pH}$ was neutral. The clean water flux was measured after the cleaning procedure to confirm that it was within $10 \%$ of the initial water flux.

\section{Chemical Analysis}

All samples were thawed at $4^{\circ} \mathrm{C}$ for analysis. Total solids were measured by air drying in an oven (AOAC International, 2000; 990.20), whereas total nitrogen ( TN), noncasein nitrogen (NCN), and NPN content were determined using Kjeldahl methods (991.20, 998.05, and 991.21, respectively; AOAC International, 2000). True protein (TP) content was calculated as $(\mathrm{TN}-\mathrm{NPN}) \times 6.38$, casein content was calculated as $(\mathrm{TN}-\mathrm{NCN}) \times 6.38$, and SP content calculated as $(\mathrm{NCN}-\mathrm{NPN}) \times 6.38$.

\section{Determination of Process Efficiency}

To assess the concentration and DF process efficiencies, mass balance calculations were used for SP and casein according to the method of Zulewska et al. (2009). The total weight of SP in skim milk and permeate (e.g., $\mathrm{VCF}=2.5 \times)$ was calculated and the weight in the retentate was then estimated by subtracting the permeate SP weight from the skim milk SP weight.

The rejection coefficient $(\sigma)$ given by equation 1 was used to evaluate the overall MF membrane performance:

$$
\sigma_{\mathrm{CN} \text { or SP }}=1-\frac{C_{P}}{C_{R}}
$$

where $C_{P}$ and $C_{R}$ represent respectively permeate and retentate casein or $\mathrm{SP}$ concentrations. Ideally, $\sigma_{\mathrm{CN}}$ should be equal to 1 and $\sigma_{\mathrm{SP}}$ should be equal to 0 following MF of skim milk. The SP removal rate $(\mathrm{kg} / \mathrm{h}$ per $\mathrm{m}^{2}$ ) was calculated by multiplying the permeate flux at a given VCF during MF by the SP concentration in the corresponding permeate sample.

\section{Energy Consumption Measurement}

Energy consumption was calculated from experimental measurements using a digital multimeter (modelr 3000FC, Fluke, Mississauga, ON, Canada) that recorded current voltage $(U)$ and intensity $(I)$ of the feed pumps and the retentate recirculation pump. Equation 2 was used to calculate the real power consumption $\left(\mathrm{W}_{\text {applied }}\right)$ of the 3 -phase motors (Farooque et al., 2008):

$$
\mathrm{W}_{\text {applied }}=\sqrt{3} \times U \times I \times \eta,
$$

where $\eta$ is the pump efficiency. As all pumps had different efficiencies during operation, the $\eta$ value was assumed to be 0.65 , as reported by Adams and Barbano (2016). Equation 3 was applied to convert real power consumption to kilowatt-hours:

$$
\mathrm{kWh}=\frac{\mathrm{W}_{\text {applied }} \times \text { Time }(\mathrm{h})}{1,000} .
$$

Energy consumption data were used to compare the energy required to remove a kilogram of permeate $(\mathrm{kWh} /$ $\mathrm{kg}$ of permeate) and SP (kWh/kg of SP) in each experiment. In our system, the recirculation pump accounted for only $34 \%$ of all energy required, which is lower than expected, as the recirculation flow rate is much greater than the feed flow rate in a tubular configuration (Cheryan, 1998). This is due the simultaneous use of 2 feed pumps that were oversized so that the system could also be used for UF, nanofiltration, or reverse osmosis. In the dairy industry, a MF system for skim milk would obviously have more suitably sized pumps to reduce power consumption.

\section{Membrane Fouling Characterization}

Membrane fouling was characterized using the resistance-in-series model (Bae and Tak, 2005),

$$
\mathrm{R}_{\mathrm{t}}=\mathrm{R}_{\mathrm{m}}+\mathrm{R}_{\mathrm{c}}+\mathrm{R}_{\mathrm{f}}
$$

where $R_{t}$ is the total resistance $\left(\mathrm{m}^{-1}\right), \mathrm{R}_{\mathrm{m}}$ is the membrane resistance $\left(\mathrm{m}^{-1}\right), \mathrm{R}_{\mathrm{c}}$ is the reversible resistance $\left(\mathrm{m}^{-1}\right)$, and $\mathrm{R}_{\mathrm{f}}$ is the irreversible resistance $\left(\mathrm{m}^{-1}\right)$. Reversible resistance is caused by the cake layer on the membrane surface, and irreversible resistance is due to pore plugging and irreversible adsorption of foulants onto the membrane (Bae and Tak, 2005). All types of resistances can be calculated using the following equations: 


$$
\begin{gathered}
\mathrm{R}_{\mathrm{m}}=\frac{\Delta \mathrm{P}_{\mathrm{T}}}{\mu \mathrm{J}_{\mathrm{w}}}, \\
\mathrm{R}_{\mathrm{c}}=\frac{\Delta \mathrm{P}_{\mathrm{T}}}{\mu \mathrm{J}_{\mathrm{AS}}}-\mathrm{R}_{\mathrm{m}},
\end{gathered}
$$

and

$$
\mathrm{R}_{\mathrm{f}}=\frac{\Delta \mathrm{P}_{\mathrm{T}}}{\mu \mathrm{J}_{\mathrm{w}}^{\prime}}-\mathrm{R}_{\mathrm{m}}
$$

where $\Delta \mathrm{P}_{\mathrm{T}}$ is the TMP $(\mathrm{Pa}), \mu$ the permeate viscosity $(\mathrm{Pa} \cdot \mathrm{s}), \mathrm{J}_{\mathrm{w}}$ is the clean water flux $\left(\mathrm{m}^{3} / \mathrm{m}^{2}\right.$ per second $)$, $\mathrm{J}^{\prime}{ }_{\mathrm{w}}$ is the fouled water flux $\left(\mathrm{m}^{3} / \mathrm{m}^{2}\right.$ per second), and $\mathrm{J}_{\mathrm{AS}}$ is the permeate flux $\left(\mathrm{m}^{3} / \mathrm{m}^{2}\right.$ per second $)$ at the end of the MF procedure (Bae and Tak, 2005). Water has a $\mu$ value of $0.547 \mathrm{mPa} \cdot \mathrm{s}$ (Weast et al., 1988), whereas MF permeate from skim milk has a $\mu$ value of 0.650 $\mathrm{mPa} \cdot \mathrm{s}$ (Adams et al., 2015). Although slight changes in permeate viscosity might occur during DF due to dilution with water, the value for MF permeate of skim milk was used.

For equivalent processing parameters (temperature, cross-flow velocity, TMP, feed composition, and so on), resistance is a good indicator of the type of fouling during filtration. For example, a high $\mathrm{R}_{\mathrm{c}}$-to- $\mathrm{R}_{\mathrm{t}}$ ratio indicates that the drop in flux is caused mostly by caking, whereas a high $R_{f}$-to- $R_{t}$ ratio indicates that the drop is caused mostly by pore plugging (Bae and Tak, 2005).

\section{Statistical Analysis}

Analyses were conducted using SAS University Edition (Version 3.4, SAS Institute Inc., Cary, NC). Significant differences between means were determined using the GLM procedure and Tukey tests with $P \leq$ 0.05 as the criterion.

\section{RESULTS}

\section{Determination of Optimal TMP for SP Removal}

As shown in Figure 2, mean permeate flux increased linearly with TMP up to $179 \mathrm{kPa}$. The critical flux was reached apparently between 179 and $207 \mathrm{kPa}$, as the relationship between flux and TMP was no longer linear in this range, whereas the limiting flux was not reached at the pressure levels tested. At each pressure level, the permeate flux remained stable during the 45min periods, meaning that no major membrane fouling occurred.

No significant differences $(P>0.05)$ were observed in the general composition of permeates and retentates

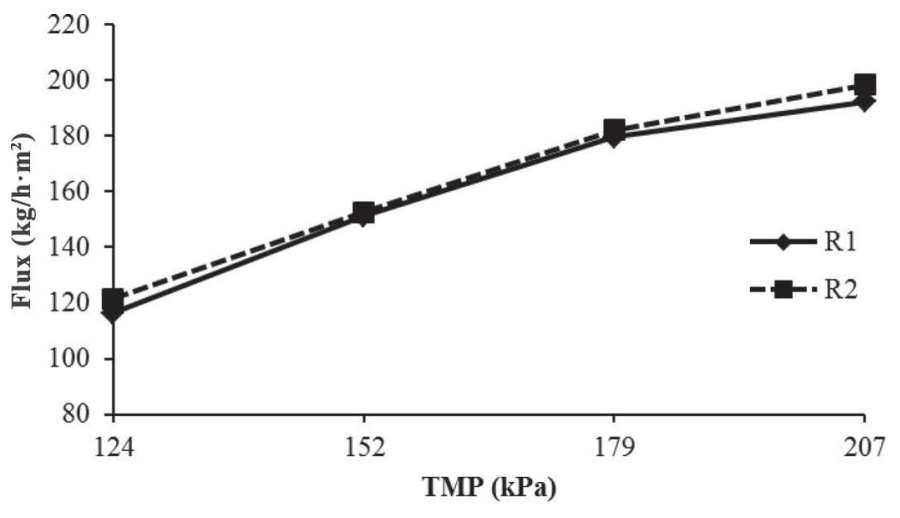

Figure 2. Permeate flux at different transmembrane pressures (TMP) during microfiltration of skim milk at $50^{\circ} \mathrm{C} . \mathrm{R} 1=$ replicate 1 ; $\mathrm{R} 2=$ replicate 2 . Flux was measured weighing the permeate collected over a period of $60 \mathrm{~s}$.

recovered at different TMP (Table 1). However, the lowest SP rejection coefficient (0.359) was calculated for $124 \mathrm{kPa}$ whereas the highest $(0.472)$ was calculated for $207 \mathrm{kPa}$. This decrease in SP transmission suggests that the critical flux was indeed reached at TMP in the 179 to $207 \mathrm{kPa}$ range.

On the basis of these results, $152 \mathrm{kPa}$ was identified as the optimal TMP for obtaining a VCF of $3 \times$ in subsequent experiments. This pressure represented a compromise between high permeate flux and low SP rejection coefficient, in addition to being well below the critical flux. At a VCF of $3 \times$ the critical flux will decrease due to an increase in the feed concentration, but a TMP of $152 \mathrm{kPa}$ should correspond to the sustainable flux, which is still acceptable for this process (Hurt et al., 2015a). The clean water flux was typically $395 \mathrm{~kg} / \mathrm{h}$ per $\mathrm{m}^{2}$ and the fouled water flux was $241 \mathrm{~kg} / \mathrm{h}$ per $\mathrm{m}^{2}$. The water flux was always restored by cleaning.

\section{SP Removal During Skim Milk Concentration and DF}

A final VCF of $3 \times$ was chosen because this a common value sought in MF processing of skim milk using GP membranes (Zulewska et al., 2009; Zulewska and Barbano, 2014). The batch process used in our study allowed accurate determination of flux and composition during skim milk concentration and DF at an average TMP of $152 \mathrm{kPa}$. As shown in Figure 3, permeate flux was highest at a VCF of $1 \times$ and decreased to approximately $80 \%$ of this value a VCF of $2 \times$. At a VCF of $3 \times$, permeate flux was approximately $53 \%$ of the initial flux.

Changes in permeate and retentate compositions during the concentration of skim milk are reported in Table 2. Significant differences were observed among retentates as a result of casein concentration as a function of VCF. Permeate contained significantly more SP 
Table 1. Mean composition ${ }^{1}$ (\% by weight) of skim milk and microfiltration permeate and retentate produced at different transmembrane pressure $(\mathrm{TMP})^{2,3}$

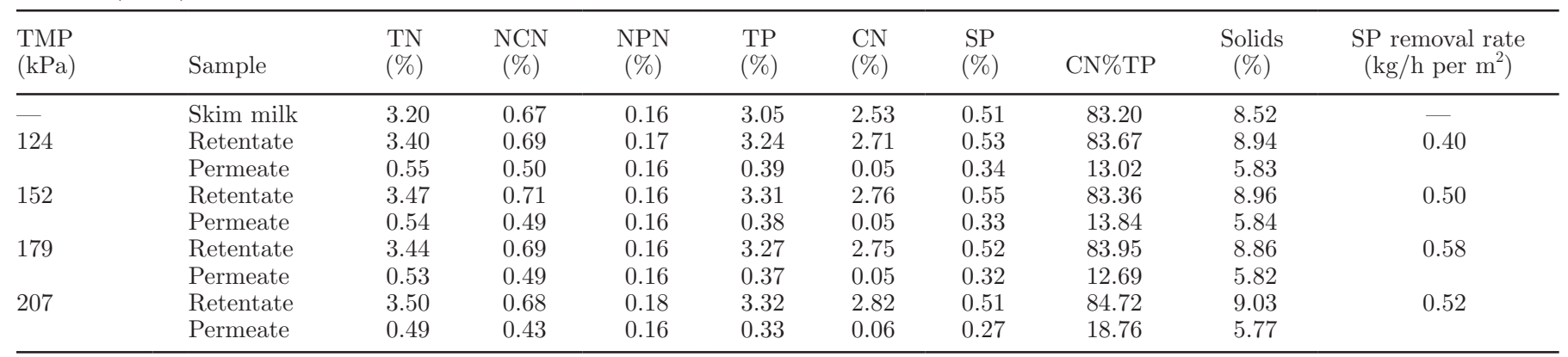

${ }^{1}$ Based on duplicate experiments.

${ }^{2} \mathrm{TN}=$ total nitrogen $\times 6.38 ; \mathrm{NCN}=$ noncasein nitrogen $\times 6.38 ; \mathrm{NPN}=$ nonprotein nitrogen $\times 6.38 ; \mathrm{TP}=$ true protein $(\mathrm{TN}-\mathrm{NPN}) ; \mathrm{CN}=$ casein $(\mathrm{TN}-\mathrm{NCN}) ; \mathrm{SP}=$ serum proteins $(\mathrm{TP}-\mathrm{CN}) ; \mathrm{CN} \% \mathrm{TP}=$ casein as percentage of true protein.

${ }^{3}$ Values in columns were not different (Tukey, $P>0.05$ ). Permeates are compared with permeates and retentates are compared with retentates.

at a $\mathrm{VCF}$ of $3 \times$ than at $1.5 \times$. However, the retentates also contained more SP, meaning that SP rejection coefficient increased overall as the VCF increased to $0.441,0.462,0.554$, and 0.559 at VCF of $1.5,2,2.5$, and $3 \times$, respectively. The increase was considerable between VCF of 2 and $2.5 \times$. As shown in Table 2, the SP removal rate tended to decrease as VCF increased. As a result of differential transmission of SP and casein, the casein as a percent of TP value increased from $82.87 \%$ in skim milk to $89.59 \%$ in the retentate at a VCF of $3 \times$. However, no significant difference was noted in casein as a percent of TP between VCF of 2 and $3 \times$, which may indicate that retentate cannot be further purified without DF. The permeate compositions reported in Table 2 also show that some casein $(0.05-0.06 \%)$ passes through no matter the VCF. The clean water flux was typically $390 \mathrm{~kg} / \mathrm{h}$ per $\mathrm{m}^{2}$ and the fouled water flux was $267 \mathrm{~kg} / \mathrm{h}$ per $\mathrm{m}^{2}$. Again, cleaning always restored the water flux.

Changes in permeation fluxes during DF are illustrated in Figure 4. The flux declined during the initial concentration, in a manner similar to that noted in the concentration experiment. At $\mathrm{VCF}$ of $3 \times$, the mean permeate flux was approximately $61 \%$ of the initial level. After the first addition of $173 \mathrm{~kg}$ of tap water (DF 1), the flux was restored to $94 \%$ of the initial flux. The flux was about $78 \%$ of the initial level when the VCF reached $3 \times$. After the second addition of $173 \mathrm{~kg}$ of tap water (DF 2), the flux was restored to $97 \%$ of the initial water flux. It decreased slightly during the last concentration to $94 \%$ of the initial water flux at VCF of $3 \times$.

Table 3 shows that TN, NCN, NPN, TP, SP, and solids decreased $(P \leq 0.05)$ in the permeate between the different stages of processing, due mostly to dilution by the DF water. For the retentate, significant differences were observed for NPN and solids between the different stages of processing. This is due to NPN and other solids (mostly lactose) consisting of molecules too small to be rejected by the membrane. The casein as a percent of TP value was expected to increase between DF 1 and 2 , as reported in the literature (Zulewska and Barbano, 2014), but remained essentially unchanged (Table 3 ). The clean water flux was typically $365 \mathrm{~kg} / \mathrm{h}$ per $\mathrm{m}^{2}$ and the fouled water flux was $272 \mathrm{~kg} / \mathrm{h}$ per $\mathrm{m}^{2}$.

\section{Energy Consumption Measurement}

In the full recycle experiment (Table 4), it was found that as the TMP increased, the kilowatt-hours per kilogram of permeate decreased significantly, except between TMP of 179 and $207 \mathrm{kPa}(P>0.05)$. However, no significant effect of TMP was noted on kilowatthours per kilogram of SP removed. In addition, the energy required tended to decrease as the TMP increased. This is because the permeate SP content remained rela-

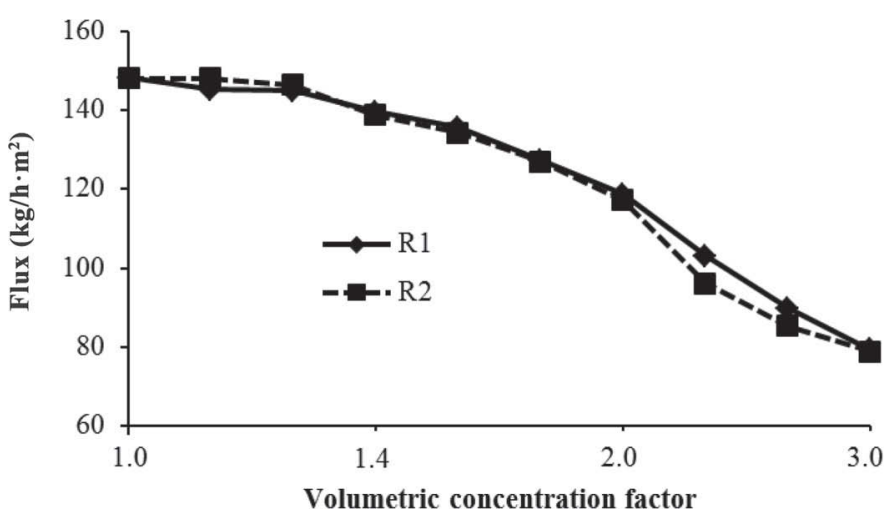

Figure 3. Permeate flux at different volumetric concentration factors during microfiltration of skim milk at $50^{\circ} \mathrm{C}$. R1 $=$ replicate $1 ; \mathrm{R} 2$ $=$ replicate 2 . Flux was measured by weighing the permeate collected over a period of $60 \mathrm{~s}$. 
Table 2. Mean composition ${ }^{1}$ (\% by weight) of skim milk and microfiltration permeate and retentate produced at different volumetric concentration factor $(\mathrm{VCF})^{2}$

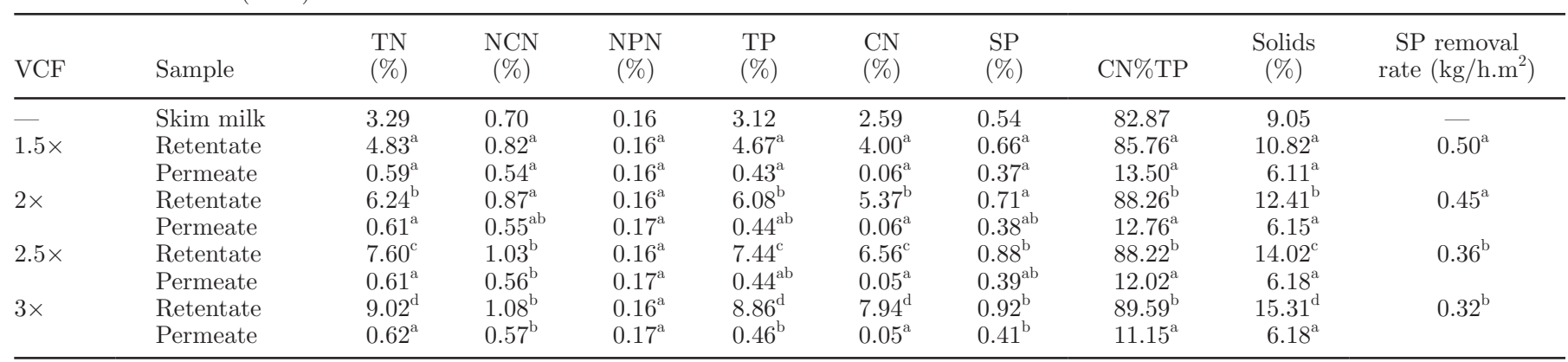

$\overline{\mathrm{a}-\mathrm{d}}$ Values in the same column without a common superscript are significantly different (Tukey, $P \leq 0.05)$. Permeates are compared with permeates and retentates are compared with retentates.

${ }^{1}$ Based on duplicate experiments.

${ }^{2} \mathrm{TN}=$ total nitrogen $\times 6.38 ; \mathrm{NCN}=$ noncasein nitrogen $\times 6.38 ; \mathrm{NPN}=$ nonprotein nitrogen $\times 6.38 ; \mathrm{TP}=$ true protein $(\mathrm{TN}-\mathrm{NPN}) ; \mathrm{CN}=$ casein $(\mathrm{TN}-\mathrm{NCN}) ; \mathrm{SP}=$ serum proteins $(\mathrm{TP}-\mathrm{CN})$; $\mathrm{CN} \% \mathrm{TP}=$ casein as percentage of true protein.

tively stable as TMP changed, whereas permeate flux increased, thus shortening the time required to obtain $1 \mathrm{~kg}$ of protein.

In the concentration experiment, significant differences were observed in kilowatt-hours per kilogram of permeate and per kilogram of SP transmitted as a function of VCF at constant TMP. Table 4 shows that energy consumption increased constantly until the VCF reached $3 \times$. However, no significant difference was observed between VCF of 1 up to $2.5 \times$. Although the MF was conducted in batch mode, the experiment can be compared with continuous MF because both are presented as processing steps. Permeate fluxes obtained at different VCF (Figure 3) can be compared using the corresponding energy consumption values in Table 4 .

Energy consumption calculated in the concentration/ DF experiment reveals that differences in kilowatthours per kilogram of permeate between the initial concentration process and DF 2 are relatively small

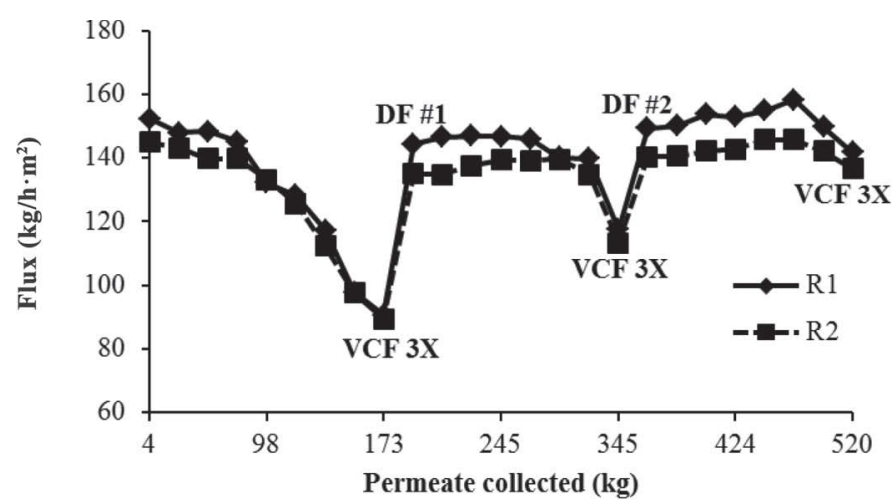

Figure 4. Permeate flux during initial concentration and subsequent diafiltration $(\mathrm{DF})$ of skim milk at $50^{\circ} \mathrm{C} \mathrm{R} 1=$ replicate 1 ; $\mathrm{R} 2=$ replicate $2 ; \mathrm{VCF}=$ volumetric concentration factor. Flux was measured by weighing the permeate collected over a period of $60 \mathrm{~s}$. but significant, due to an increase in permeate flux between processing steps. However, the differences in kilowatt-hours per kilogram of SP transmitted are more substantial and show that the first and second DF steps require respectively up to 2 and 5 times more energy than initial concentration. This large increase in energy consumption is due mainly to the lower SP content of DF permeates because of dilution with water. Whereas the energy consumption findings may not be applicable to every MF system, tendencies similar to those described in Table 4 are likely to be observed under other circumstances and are therefore relevant.

\section{DISCUSSION}

\section{Flux Performance of GP Membrane}

The fluxes reported in the present study are in general agreement with published data. The average flux at a VCF of $3 \times$ differed from one experiment to the next: $79.1 \mathrm{~kg} / \mathrm{h} . \mathrm{m}^{2}$ in the concentration experiment and 90.0 $\mathrm{kg} / \mathrm{h}$ per $\mathrm{m}^{2}$ in the concentration/DF experiment (before DF). These differences are due likely to variation in the TS contents of the batches of milk used and the VCF actually achieved at the end of filtration, as VCF is more difficult to estimate in batch mode. The fluxes were nevertheless slightly higher than those obtained in similar studies $-72.5 \mathrm{~kg} / \mathrm{h}$ per $\mathrm{m}^{2}$ by Zulewska and Barbano (2014) and $71.8 \mathrm{~kg} / \mathrm{h}$ per $\mathrm{m}^{2}$ by Zulewska et al. (2009) - whereas the overall pressures maintained (Rpi, Rpo, and Ppo) were lower. The same tendency was noted during DF, the flux reaching, on average, $115.4 \mathrm{~kg} / \mathrm{h}$ per $\mathrm{m}^{2}$ after DF 1 and $139.3 \mathrm{~kg} / \mathrm{h}$ per $\mathrm{m}^{2}$ after DF 2, compared with 84.5 and $92.7 \mathrm{~kg} / \mathrm{h}$ per $\mathrm{m}^{2}$ in a similar experiment conducted by Zulewska and Barbano (2014). 
Table 3. Mean composition ${ }^{1}$ (\% by weight) of skim milk and microfiltration permeate and retentate produced at different stages of concentration and diafiltration $(\mathrm{DF})^{2}$

\begin{tabular}{|c|c|c|c|c|c|c|c|c|c|c|}
\hline Stage of processing & Sample & $\begin{array}{l}\mathrm{TN} \\
(\%)\end{array}$ & $\begin{array}{c}\text { NCN } \\
(\%)\end{array}$ & $\begin{array}{c}\text { NPN } \\
(\%)\end{array}$ & $\begin{array}{l}\mathrm{TP} \\
(\%)\end{array}$ & $\begin{array}{l}\text { CN } \\
(\%)\end{array}$ & $\begin{array}{l}\text { SP } \\
(\%)\end{array}$ & $\mathrm{CN} \% \mathrm{TP}$ & $\begin{array}{c}\text { Solids } \\
(\%)\end{array}$ & $\begin{array}{c}\text { SP removal } \\
\text { rate } \\
\left(\mathrm{kg} / \mathrm{h} \cdot \mathrm{m}^{2}\right)\end{array}$ \\
\hline - & Skim milk & 2.96 & 0.65 & 0.16 & 2.80 & 2.31 & 0.49 & 82.58 & 8.52 & - \\
\hline After initial concentration & Permeate & $0.56^{\mathrm{a}}$ & $0.51^{\mathrm{a}}$ & $0.16^{\mathrm{a}}$ & $0.40^{\mathrm{a}}$ & $0.06^{\mathrm{a}}$ & $0.35^{\mathrm{a}}$ & $14.45^{\mathrm{a}}$ & $5.79^{\mathrm{a}}$ & \\
\hline \multirow[t]{2}{*}{ After DF 1} & Retentate & $7.45^{\mathrm{a}}$ & $0.71^{\mathrm{b}}$ & $0.06^{\mathrm{b}}$ & $7.40^{\mathrm{a}}$ & $6.74^{\mathrm{a}}$ & $0.65^{\mathrm{b}}$ & $91.20^{\mathrm{b}}$ & $9.90^{\mathrm{b}}$ & $0.18^{\mathrm{b}}$ \\
\hline & Permeate & $0.22^{\mathrm{b}}$ & $0.18^{\mathrm{b}}$ & $0.05^{\mathrm{b}}$ & $0.17^{\mathrm{b}}$ & $0.04^{\mathrm{a}}$ & $0.13^{\mathrm{b}}$ & $21.94^{\mathrm{a}}$ & $1.92^{\mathrm{b}}$ & \\
\hline
\end{tabular}

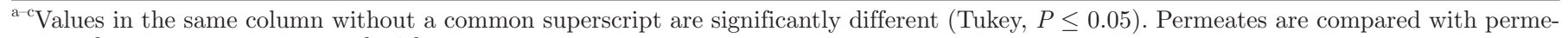
ates and retentates are compared with retentates.

${ }^{1}$ Based on duplicate experiments.

${ }^{2} \mathrm{TN}=$ total nitrogen $\times 6.38 ; \mathrm{NCN}=$ noncasein nitrogen $\times 6.38 ; \mathrm{NPN}=$ nonprotein nitrogen $\times 6.38 ; \mathrm{TP}=$ true protein $(\mathrm{TN}-\mathrm{NPN}) ; \mathrm{CN}=$ casein $(\mathrm{TN}-\mathrm{NCN}) ; \mathrm{SP}=$ serum proteins $(\mathrm{TP}-\mathrm{CN}) ; \mathrm{CN} \% \mathrm{TP}=$ casein as percentage of true protein.

A decrease in SP removal rate (Table 2) during skim milk concentration experiments indicated build-up of a fouling layer as the VCF was increased. Previous study showed that, at a VCF of $3 \times$, GP membrane achieved a $\mathrm{SP}$ removal rate of $0.37 \mathrm{~kg} / \mathrm{h}$ per $\mathrm{m}^{2}$ (Zulewska and Barbano, 2014). The results obtained in the present study are therefore consistent with those reported in the literature. The SP removal rate dropped significantly during DF steps (Table 3). Even though adding water increased the permeate flux, dilution was occurring at the same time, thus decreasing the overall efficiency of the process. The weight of permeate required to remove $1 \mathrm{~kg}$ of SP increased as tap water was added to skim milk. This value was $290 \mathrm{~kg}$ at VCF of $3 \times$ after the initial concentration, $770 \mathrm{~kg}$ after DF 1, and 1,628 kg after DF 2. In other words, DF increases considerably the volume of the stream from which the SP must be recovered.

\section{Membrane Fouling}

Clean water flux was slightly lower in the concentration/DF experiment than in the other experiments, which explains the significantly higher $(P \leq 0.05)$ calculated membrane resistance $\left(\mathrm{R}_{\mathrm{m}}\right)$ value (Figure 5$)$. However, the water flux was still within the acceptable range (within $10 \%$ of the initial water flux). At the end of the concentration experiment, the $\mathrm{R}_{\mathrm{c}}$-to- $\mathrm{R}_{\mathrm{t}}$ ratio (0.593) was higher than at the end of the concentration/ DF experiment (0.300), meaning that the fouling layer was thicker. The DF water decreased the TS content of the retentate and, hence, the thickness of the fouling layer, which increased the permeate flux and reduced the $R_{c}$-to- $R_{t}$ ratio measured at the end of the experiment. No significant difference in irreversible resistance was observed between experiments. This may indicate that most of the pore plugging appeared during the

Table 4. Power consumption during microfiltration of skim milk at $50^{\circ} \mathrm{C}$ under different transmembrane pressure (TMP), volumetric concentration factors (VCF), and diafiltration (DF) conditions

\begin{tabular}{|c|c|c|c|}
\hline \multirow[b]{2}{*}{ Item } & \multirow[b]{2}{*}{ Level } & \multicolumn{2}{|c|}{ Feed + recirculation pumps ${ }^{1}$} \\
\hline & & $\begin{array}{l}\mathrm{kWh} / \mathrm{kg} \text { of } \\
\text { permeate }\end{array}$ & $\begin{array}{c}\mathrm{kWh} / \mathrm{kg} \text { of } \\
\mathrm{SP} \text { transmitted }\end{array}$ \\
\hline TMP & $\begin{array}{l}124 \mathrm{kPa} \\
152 \mathrm{kPa} \\
179 \mathrm{kPa} \\
207 \mathrm{kPa}\end{array}$ & $\begin{array}{l}0.094^{\mathrm{a}} \\
0.073^{\mathrm{b}} \\
0.062^{\mathrm{c}} \\
0.057^{\mathrm{c}}\end{array}$ & $\begin{array}{l}28.29^{\mathrm{a}} \\
22.45^{\mathrm{a}} \\
19.27^{\mathrm{a}} \\
21.54^{\mathrm{a}}\end{array}$ \\
\hline $\begin{array}{l}\text { VCF reached } \\
(\text { at } \mathrm{TMP}=152 \mathrm{kPa})\end{array}$ & $\begin{array}{l}1-1.5 \times \\
1.5-2 \times \\
2-2.5 \times \\
2.5-3 \times\end{array}$ & $\begin{array}{l}0.093^{\mathrm{a}} \\
0.099^{\mathrm{a}} \\
0.113^{\mathrm{ab}} \\
0.143^{\mathrm{b}}\end{array}$ & $\begin{array}{l}24.92^{\mathrm{a}} \\
25.73^{\mathrm{a}} \\
28.99^{\mathrm{ab}} \\
34.98^{\mathrm{b}}\end{array}$ \\
\hline Concentration/DF to $\mathrm{VCF}=3 \times(\mathrm{TMP}=152 \mathrm{kPa})$ & $\begin{array}{l}\text { Concentration } \\
\text { DF \#1 } \\
\text { DF \#2 }\end{array}$ & $\begin{array}{l}0.089^{\mathrm{a}} \\
0.083^{\mathrm{ab}} \\
0.077^{\mathrm{b}}\end{array}$ & $\begin{array}{r}25.83^{\mathrm{a}} \\
63.99^{\mathrm{b}} \\
124.85^{\mathrm{c}}\end{array}$ \\
\hline
\end{tabular}

${ }^{\mathrm{a}-\mathrm{c}}$ Means in the same column without a common superscript are significantly different (Tukey, $P \leq 0.05$ ). Comparisons were made with results from the same experiment only.

${ }^{1}$ The recirculation pump accounted for $34 \%$ of all energy required. 
initial concentration to VCF of $3 \times$ and could not be reversed by adding tap water.

\section{SP and Casein Transmission}

As the goal of this MF process is to retain all casein in the retentate, it is important to measure the quantity that crossed the membrane. Those casein are considered lost because they cannot be used for cheesemaking, thus decreasing the profitability of the process. The transmission of casein through GP membrane has been found higher than through spiral-wound or UTP membranes (Zulewska et al., 2009). As shown in Figure $6 \mathrm{a}$, approximately $1.4 \%$ of the total casein crossed the membrane at a VCF of $3 \times$. Diafiltration increased this loss to 2.8 and $3.8 \%$ (DF 1 and 2, respectively; Figure $6 \mathrm{~b})$. It has been found previously that DF allows more casein to pass through the membrane than simple concentration (Zulewska and Barbano, 2014). During our concentration/DF experiment, the permeate casein concentration was relatively constant from one stage
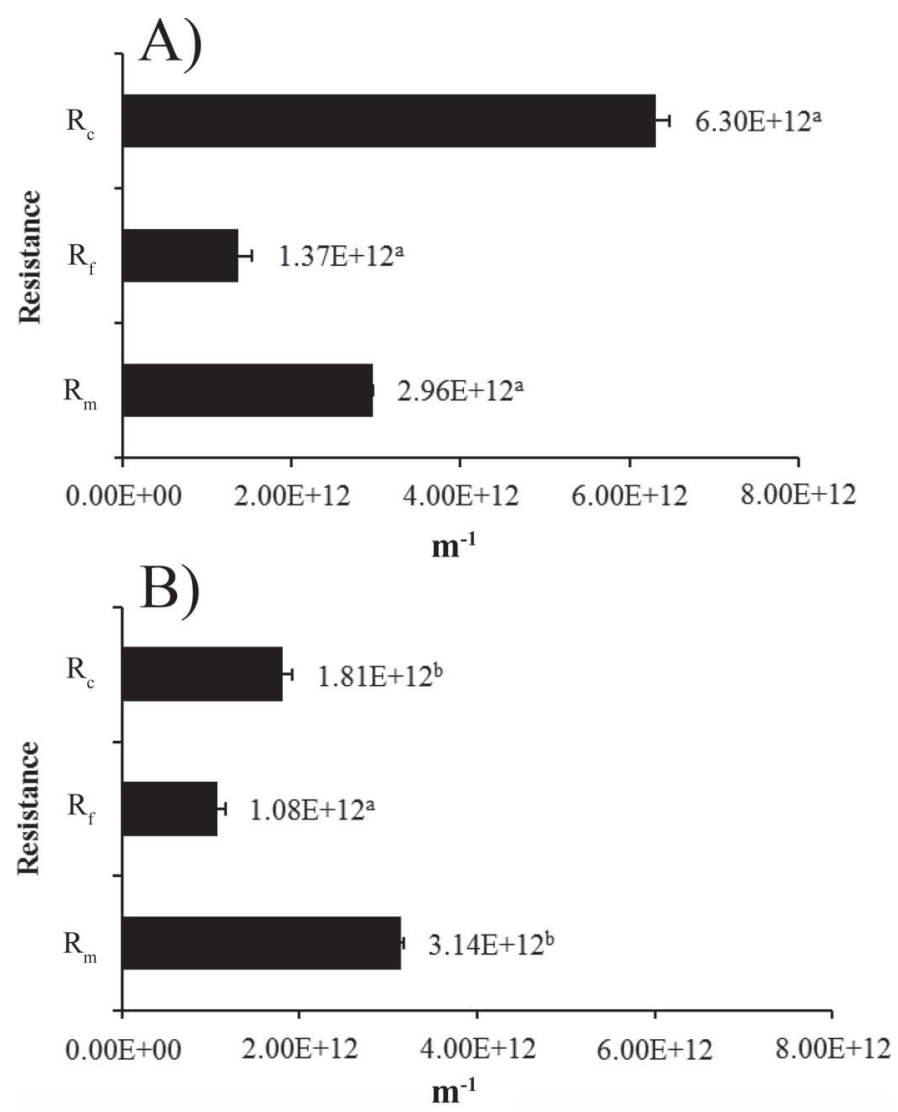

Figure 5. Reversible $\left(R_{c}\right)$, irreversible $\left(R_{f}\right)$, and membrane resistance $\left(\mathrm{R}_{\mathrm{m}}\right)$ after initial concentration of skim milk to volumetric concentration factor $(\mathrm{VCF})=3 \times(\mathrm{A})$ and reconcentration to $\mathrm{VCF}=3 \times$ after 2 dialfiltrations (B). Means in the same type of resistance without a common letter (a,b) are significantly different (Tukey, $P \leq 0.05$ ). to the next whereas the SP concentration decreased, which indicates that the weight of SP removed by $1 \mathrm{~kg}$ of casein loss decreased. At a $\mathrm{VCF}$ of $3 \times$, this ratio was $5.9,3.6$, and $2.0 \mathrm{~kg}$, respectively, after initial concentration, DF 1, and DF 2, indicating increased contamination of permeate by casein under conditions of DF.

In terms of the percentage of SP removed at the end of processing (Figure 6), results were better in previous studies, such as $56.0 \%$ in Zulewska and Barbano (2014) and $61.0 \%$ in Zulewska et al. (2009), whether compared with the concentration (47.6\%) or the concentration/ DF (47.0\% before DF) experiments. This might be due to a higher SP rejection coefficient in our experiment, which could result from higher permeation fluxes (closer to the limiting flux) or to a different start-up procedure. Again, SP removal from skim milk was $64.7 \%$ after DF 1 and $73.2 \%$ after DF 2, compared with 82.6 and $96.5 \%$ obtained by Zulewska and Barbano (2014) after similar DF steps. Although the differences appear considerable, this mass balance calculation might not be the best way to evaluate the efficiency of the process. These calculations overestimate the quantity of SP transmitted because they do not take into consideration the amount remaining in the retentate, thus reducing the accuracy of the mass balance.

\section{Process Efficiency}

Process efficiency was evaluated in terms of SP removal rate, energy consumption, total SP removed from skim milk, weight of permeate required to remove $1 \mathrm{~kg}$ of SP, weight of SP removed by $1 \mathrm{~kg}$ of casein loss in the permeate, SP rejection coefficient, casein as a percent of TP value of the retentate, membrane resistance, and permeate flux. None of these parameters indicated clearly what the optimal VCF was or whether or not DF improved process efficiency. The 3 most important parameters from a dairy processing perspective were then selected for the comparison of the experimental conditions: total energy consumption, cumulative loss of casein, and SP remaining in the retentate. All values were converted to percentages of the maximum value to make a 3 -axis figure in which the lowest value represents the best option. Figure $7 \mathrm{a}$ shows clearly that VCF of $1.5 \times$ has a major advantage in terms of 2 of the 3 parameters, whereas VCF of $3 \times$ is the worst for 2 parameters but best in terms of SP remaining in the retentate. Figure $7 \mathrm{~b}$ shows that simple concentration (to VCF of $3 \times$ ) is the best in terms of total energy consumption, but leaves more SP in the retentate than does either DF. For example, the second DF step required $45 \%$ more energy and resulted in $35 \%$ more casein loss in the permeate, whereas only $13 \%$ 

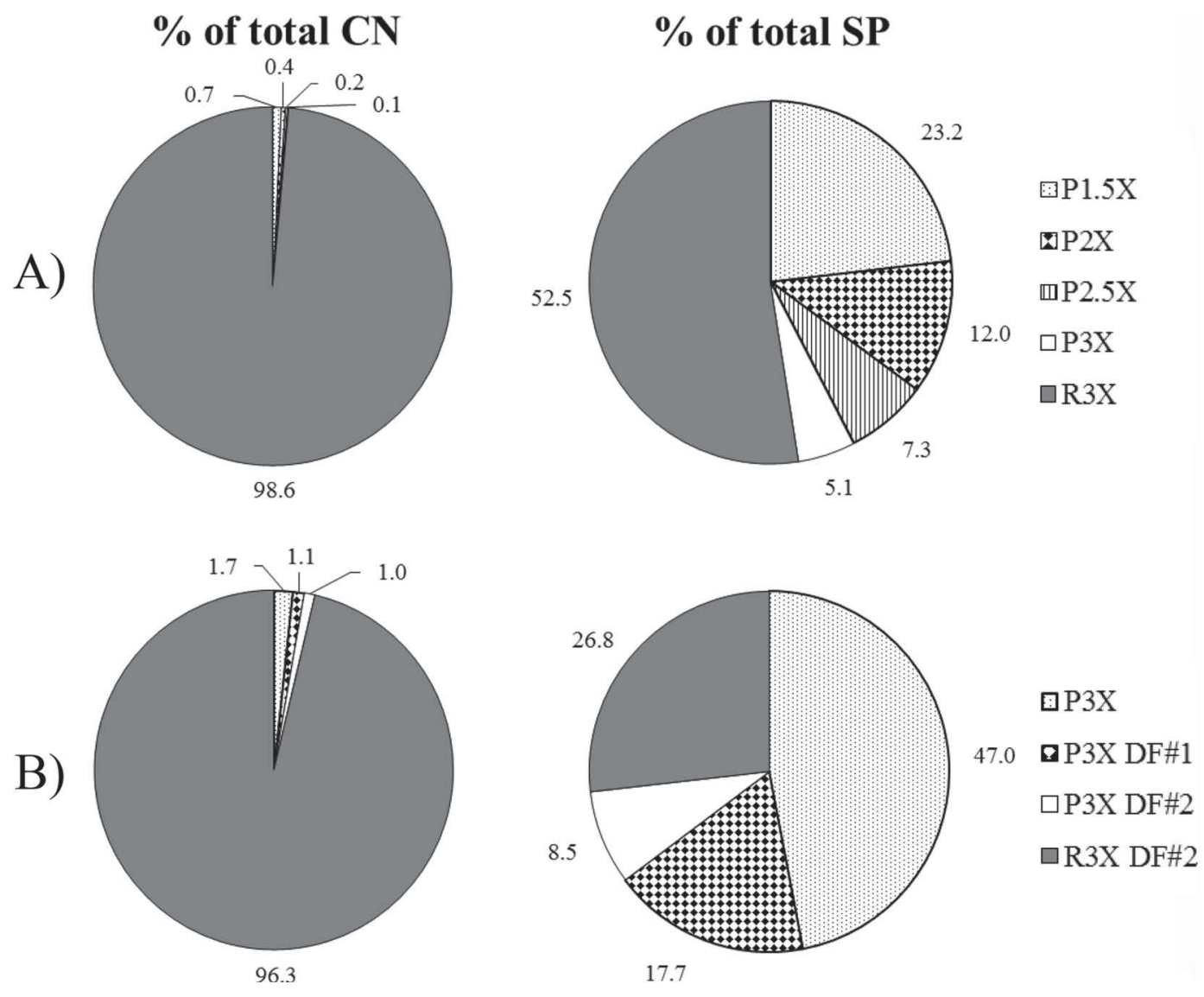

Figure 6. Mass balance of casein $(\mathrm{CN})$ and serum proteins $(\mathrm{SP})$ at $(\mathrm{A})$ different volumetric concentration factors $(\mathrm{VCF})$ and $(\mathrm{B})$ at $\mathrm{VCF}=$ $3 \times$ after initial concentration then first and second diafiltration (DF).

more SP was removed from the retentate compared with the first DF step.

It is not possible to compare Figures $7 \mathrm{a}$ and $7 \mathrm{~b}$ because the units are expressed in relative percentage, but it is reasonable to expect a lower VCF to require less total energy and result in a smaller total loss of casein but a higher retentate SP content compared with DF. Dairy processors of course might not all attach the same value to each of these 3 parameters. Depending on economic conditions, some might value transmitted SP more whereas some might consider casein loss or total energy cost to be more important. In other words, these figures can be used to assess the overall process efficiency, but do not give a specific answer, as each dairy-processing facility has its own economic reality.

In all cases, the total amount of permeate generated must be taken into consideration. For simple concentration at $\mathrm{VCF}$ of $3 \times, 2 \mathrm{~kg}$ are generated for each kilogram of retentate, whereas 4 and $6 \mathrm{~kg}$ of permeate are generated for each kilogram of retentate after 1 and $2 \mathrm{DF}$, respectively. A dairy processor must be able to reduce the environmental impact of this waste stream efficiently. For example, cheese whey has a biochemical oxygen demand of 40 to $60 \mathrm{~g} / \mathrm{L}$ and a chemical oxygen demand of 50 to $80 \mathrm{~g} / \mathrm{L}$, lactose being responsible for $90 \%$ of both values (Kim et al., 2006). Although the composition of MF permeate differs from that of cheese whey, its lactose content is similar. Means of valorization of the MF permeate were not evaluated in our study, but it is clear that more permeate equals more processing costs because it mostly contains water and that lactose and SP must be further purified (evaporation, filtration, spray-drying, crystallization, and so on) to gain value.

\section{Efficient Process Proposal}

As stated by Zulewska and Barbano (2014), operating at higher flux improves the economic feasibility of the MF process by decreasing the membrane surface area requirement. Membrane surface area represents a huge capital cost, particularly for GP membrane (approximately $\$ 3,100 / \mathrm{m}^{2}$, excluding module). A larger membrane surface area also means higher operating costs (e.g., for cleaning, maintenance, and pumping) and greater losses of milk due to dilution in the filtra- 

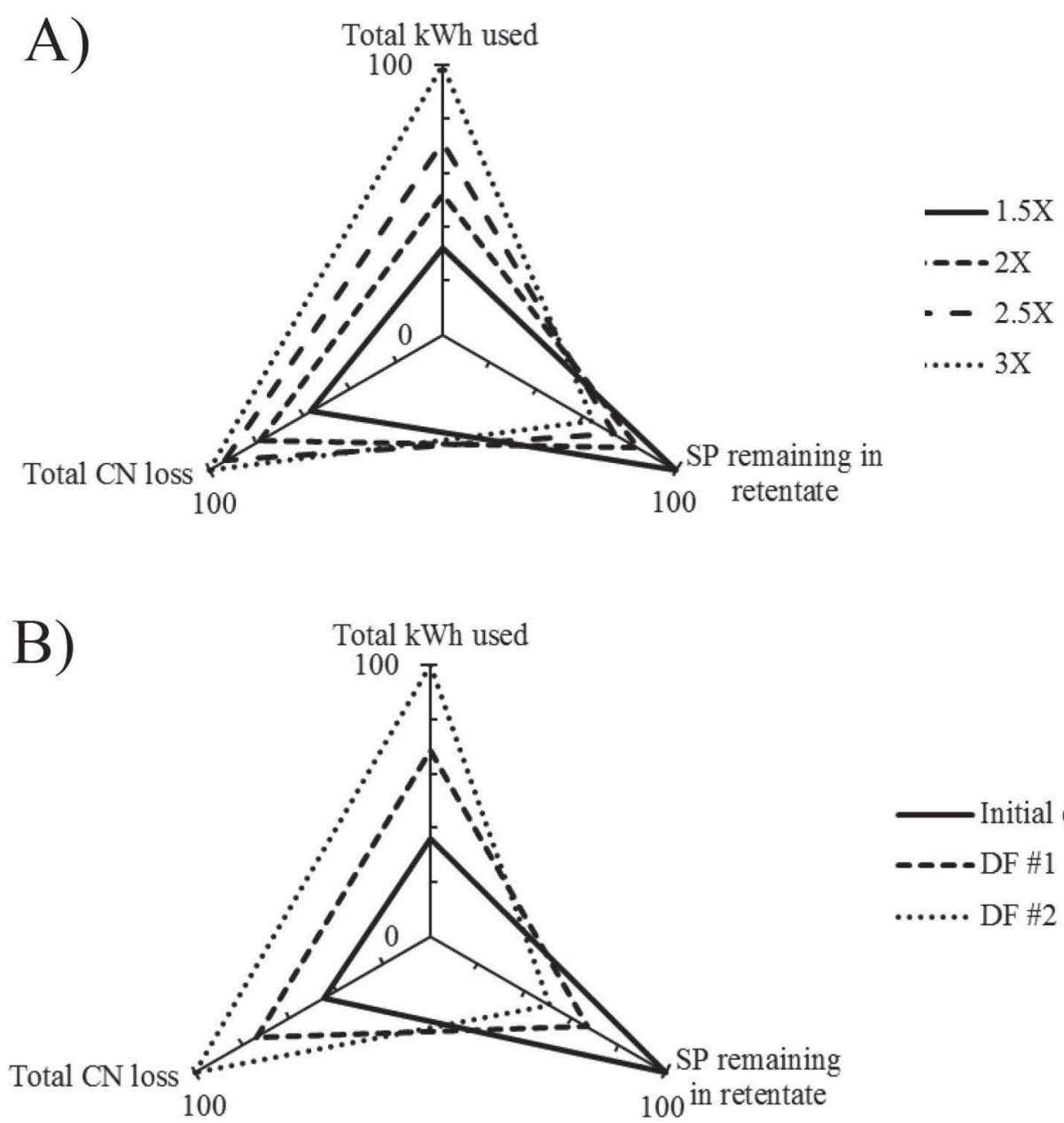

Initial concentration
...... DF \#2

Figure 7. Relative percentages of cumulative kilowatt-hours used, casein (CN) loss in the permeate, and serum proteins (SP) in the retentate (A) at different volumetric concentration factors $(\mathrm{VCF})$ and $(\mathrm{B})$ at $\mathrm{VCF}=3 \times$ after initial concentration then first and second diafiltration (DF).

tion system dead volume at the beginning and end of production (Skrzypek and Burger, 2010).

As cheese yield is directly proportional to the casein content of the cheese milk (Neocleous et al., 2002a), casein-enriched MF retentate can be added in different proportions to standardize cheese milk. Table 5 shows that, for a given final casein concentration of cheese milk, the proportion of MF retentate required decreases as the VCF of the retentate increases whereas the permeate and SP obtained change very little. The membrane surface area required increases with VCF of the MF retentate due to decreasing permeate flux. As the initial whole milk skimmed for the production of MF retentate does not provide enough fat for cheesemaking, additional cream is required for standardization of the cheese milk. The loss of casein in the permeate is expected to be similar at each VCF, as casein content is stable (Table 2), but energy consumption may increase at a higher VCF because of the lower permeate flux and the larger size of the MF system. The required VCF of
MF retentate increases with the required casein concentration of the cheese milk, resulting in increased permeate and SP production. Regardless of the cheese milk standardization scenario being examined, many factors must be considered to evaluate the economic feasibility of the process, including the amount of permeate produced, the current value of SP, the costs associated with membrane surface area, and the benefit associated with the increased productivity of the cheesemaking process. The membrane surface area requirements in Table 5 are based on permeate fluxes in Figure 3, and, as mentioned, permeate flux could be lowered to be closer to the critical flux to get a lower SP rejection coefficient. This would probably increase the surface area required, but at the same time more SP would be obtained for the same final casein concentration in the cheese milk.

Table 5 suggests that the best way to reduce the membrane surface area requirement is to improve flux by using a lower VCF, which improves the pro- 
Table 5. Proportions of whole milk, cream, and different microfiltration retentates required to standardize $1 \mathrm{million} \mathrm{kg}$ of cheese milk at different casein concentrations in an 18 -h run

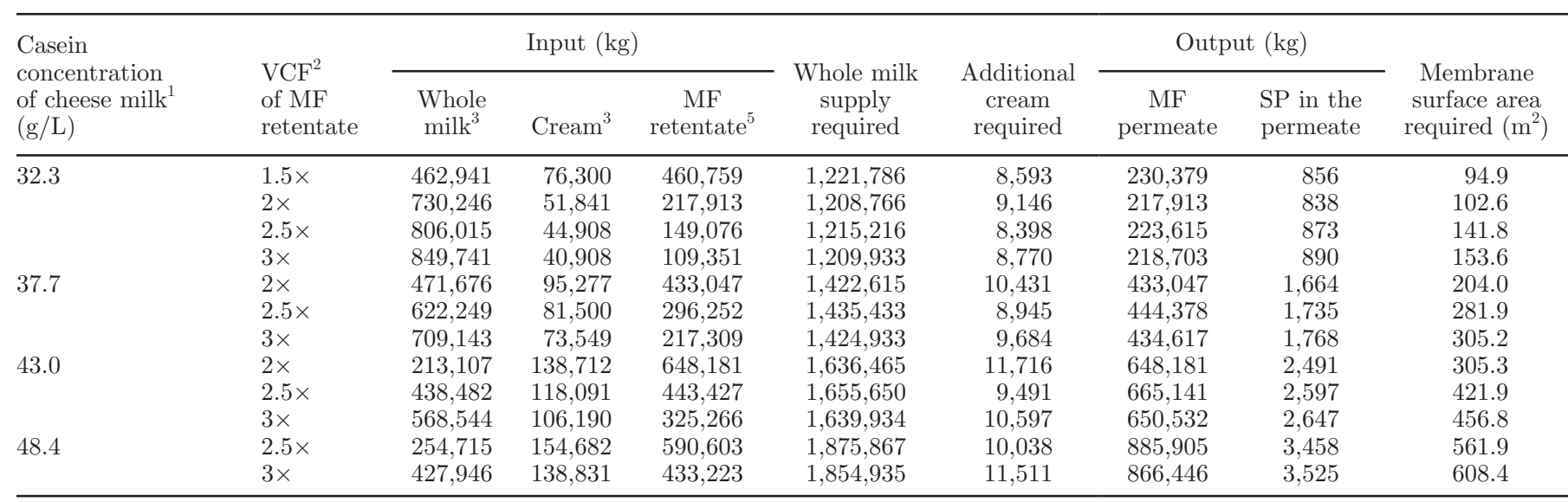

${ }^{1} \mathrm{CN}$-to-fat ratio: 0.68 , as recommended by Neocleous et al. (2002a).

${ }^{2} \mathrm{VCF}=$ volumetric concentration factor.

${ }^{3}$ Whole milk: $3.7 \%$ fat, $2.7 \%$ casein.

${ }^{4}$ Cream: $40.0 \%$ fat, $1.8 \%$ casein.

${ }^{5}$ Casein content from Table 2, no fat.

cess efficiency. In fact, studies have shown that the MF retentate can be used for cheese production, and, although the results are variable, a lower casein concentration factor offers better results (Neocleous et al., 2002b; Schreier et al., 2010). In their evaluation of the economic feasibility of using MF-processed skim milk for cheesemaking, Papadatos et al. (2003) concluded that increasing the VCF beyond $2 \times$ provides no additional benefit because of the higher processing cost. Nevertheless, those authors showed that the use of MF retentate was more cost-efficient than conventional cheesemaking and other milk fortification methods, such as the use of condensed milk or nonfat dry milk. However, their study focused primarily on the addition of $\mathrm{MF}$ retentate with a $\mathrm{VCF}$ of 2 or $3 \times$ to raw milk and cream to produce the equivalent of a retentate with a VCF of $1.25 \times$. The conclusions of Papadatos et al. (2003) could be strengthened now that the superiority of GP membranes over UTP systems has been proven for MF of skim milk. Considering those factors, dairy processors should view MF as a way of adding value to the conventional cheesemaking process by producing a SP-enriched permeate and a casein-enriched retentate which could replace the use of UF to increase protein concentration of cheese milk. Compared with UF, MF allows higher permeate flux and requires lower operating pressures.

If the desired fraction is MCC, DF should be used to obtain a retentate with as little $\mathrm{SP}$ as possible. Although casein products such as MCC are being replaced progressively by milk protein concentrates or isolates (Lagrange et al., 2015), the literature on their production is abundant. Zulewska and Barbano (2014) estimated that the use of GP membrane allows reduction of the total surface area needed to process 1 million $\mathrm{kg}$ of skim milk (over an 18-h run) to 1,208 $\mathrm{m}^{2}$, compared with $2,051 \mathrm{~m}^{2}$ for a UTP system. They estimated that this process would allow removal of more than $95 \%$ of the SP from the milk, but that $2 \mathrm{DF}$ steps would be needed, meaning that, overall, 1 million $\mathrm{kg}$ of retentate and 2 million $\mathrm{kg}$ of permeate would be generated (Zulewska and Barbano, 2014). Although such a process is theoretically feasible, it would be less efficient than the standardization of cheese milk with MF retentate. Also, dairy processor should have the equipment needed to manage all those effluents.

\section{CONCLUSIONS}

This study presents an analysis that will help dairy processors to identify the key parameters for optimizing their investment in a GP membrane system. Whereas achieving a higher VCF or using DF allows the separation of more SP from skim milk, these approaches do not necessarily result in a more efficient process. In fact, a lower VCF allows higher permeate flux and a lower SP rejection coefficient, while requiring less energy and reducing casein loss. Diafiltration is a viable option if the dairy processor wants to produce MCC, as it allows separation of almost all of the SP from skim milk. Milk used for cheesemaking should be standardized with MF retentate made at the lowest possible VCF. Dairy processors should use skim milk MF retentate to increase cheese production capacity, while 
generating permeate with added value compared with cheese whey. Although the results of this study show some tendencies regarding the efficiency of processing skim milk using GP MF membrane, the economic feasibility of the process remains the main factor that will determine whether or not this technology should be used at a large scale.

\section{ACKNOWLEDGMENTS}

This research was funded by Natural Sciences and Engineering Research Council of Canada (NSERC), Novalait Inc., Fonds de recherche du Québec-Nature et technologies (FRQNT), and Canadian Dairy Commission (CDC). The authors thank Diane Gagnon, Mélanie Martineau, Pascal Lavoie, and Matthieu Ruiz from the Department of Food Science at Laval University for their assistance during the experiments.

\section{REFERENCES}

Adams, M. C., and D. M. Barbano. 2013. Serum protein removal from skim milk with a 3 -stage, $3 \mathrm{x}$ ceramic Isoflux membrane process at 50 degrees C. J. Dairy Sci. 96:2020-2034. http://dx.doi. org/10.3168/jds.2012-6007.

Adams, M. C., and D. M. Barbano. 2016. Effect of ceramic membrane channel diameter on limiting retentate protein concentration during skim milk microfiltration. J. Dairy Sci. 99:167-182. http:// dx.doi.org/10.3168/jds.2015-9897.

Adams, M. C., E. E. Hurt, and D. M. Barbano. 2015. Effect of soluble calcium and lactose on limiting flux and serum protein removal during skim milk microfiltration. J. Dairy Sci. 98:7483-7497. http://dx.doi.org/10.3168/jds.2015-9474.

Bacchin, P. 2004. A possible link between critical and limiting flux for colloidal systems: Consideration of critical deposit formation along a membrane. J. Membr. Sci. 228:237-241. http://dx.doi. org/10.1016/j.memsci.2003.10.012.

Bacchin, P., P. Aimar, and R. W. Field. 2006. Critical and sustainable fluxes: Theory, experiments and applications. J. Membr. Sci. 281:42-69. http://dx.doi.org/10.1016/j.memsci.2006.04.014.

Bae, T. H., and T. M. Tak. 2005. Interpretation of fouling characteristics of ultrafiltration membranes during the filtration of membrane bioreactor mixed liquor. J. Membr. Sci. 264:151-160. http:// dx.doi.org/10.1016/j.memsci.2005.04.037.

Cheryan, M. 1998. Ultrafiltration and Microfiltration Handbook. CRC Press, Lancaster, PA.

Farooque, A. M., A. T. M. Jamaluddin, A. R. Al-Reweli, P. A. M. Jalaluddin, S. M. Al-Marwani, A. A. Al-Mobayed, and A. H. Qasim. 2008. Parametric analyses of energy consumption and losses in SWCC SWRO plants utilizing energy recovery devices. Desalination 219:137-159. http://dx.doi.org/10.1016/j.desal.2007.06.004.

Fernández García, L., and F. A. Riera Rodríguez. 2015. Microfiltration of milk with third generation ceramic membranes. Chem. Eng. Commun. 202:1455-1462. http://dx.doi.org/10.1080/00986445.20 14.950731 .

Garcera, D., and E. Toujas. 2002. Graded permeability macroporous support for crossflow filtration. Societe des Ceramiques Techniques, assignee. US Pat. No. 6,375,014B1.

Gésan-Guiziou, G., E. Boyaval, and G. Daufin. 1999. Critical stability conditions in crossflow microfiltration of skimmed milk: Transi- tion to irreversible deposition. J. Membr. Sci. 158:211-222. http:// dx.doi.org/10.1016/S0376-7388(99)00017-4.

Holm, S., R. Malmberg, and K. Svensson. 1990. Arrangement in membrane filter. Alfa-Laval, US Pat. No. 4.906.362.

Hu, K., and J. M. Dickson. 2015. Membrane Processing for Dairy Ingredient Separation. IFT Press. Wiley-Blackwell, Hoboken, NJ.

Hurt, E. E., M. C. Adams, and D. M. Barbano. 2015a. Microfiltration: Effect of channel diameter on limiting flux and serum protein removal. J. Dairy Sci. 98:3599-3612. http://dx.doi.org/10.3168/ jds.2014-9225.

Hurt, E. E., M. C. Adams, and D. M. Barbano. 2015b. Microfiltration: Effect of retentate protein concentration on limiting flux and serum protein removal with 4-mm-channel ceramic microfiltration membranes. J. Dairy Sci. 98:2234-2244. http://dx.doi. org/10.3168/jds.2014-9032.

Jimenez-Lopez, J. E., N. Leconte, O. Dehainault, C. Geneste, L. Fromont, and G. Gésan-Guiziou. 2008. Role of milk constituents on critical conditions and deposit structure in skimmilk microfiltration $(0.1 \mu \mathrm{m})$. Separ. Purif. Tech. 61:33-43. http://dx.doi. org/10.1016/j.seppur.2007.09.023.

Kim, H.-O., Y.-J. Wee, J.-N. Kim, J.-S. Yun, and H.-W. Ryu. 2006. Production of lactic acid from cheese whey by batch and repeated batch cultures of Lactobacillus sp. RKY2. Appl. Biochem. Biotechnol. 131:694-704. http://dx.doi.org/10.1385/ABAB:131:1:694.

Lagrange, V., D. Whitsett, and C. Burris. 2015. Global market for dairy proteins. J. Food Sci. 80:A16-A22. http://dx.doi org/10.1111/1750-3841.12801.

Neocleous, M., D. M. Barbano, and M. A. Rudan. 2002a. Impact of low concentration factor microfiltration on milk component recovery and cheddar cheese yield. J. Dairy Sci. 85:2415-2424.

Neocleous, M., D. M. Barbano, and M. A. Rudan. 2002b. Impact of low concentration factor microfiltration on the composition and aging of cheddar cheese. J. Dairy Sci. 85:2425-2437.

Noble, R. D., and R. Agrawal. 2005. Separations research needs for the 21st century. Ind. Eng. Chem. Res. 44:2887-2892. http://dx.doi. org $/ 10.1021$ ie0501475.

Papadatos, A., M. Neocleous, A. M. Berger, and D. M. Barbano. 2003. Economic feasibility evaluation of microfiltration of milk prior to cheesemaking. J. Dairy Sci. 86:1564-1577.

Saboya, L. V., and J. L. Maubois. 2000. Current developments of microfiltration technology in the dairy industry. Lait 80:541-553. / http://dx.doi.org/10.1051/lait:2000144.

Sandblom, R. M. 1978. Filtering process. Alfa-Laval, assignee. US Pat. No. $4,105,547$.

Schreier, K., K. Schafroth, and A. Thomet. 2010. Application of crossflow microfiltration to semi-hard cheese production from milk retentates. Desalination 250:1091-1094. http://dx.doi.org/10.1016/j. desal.2009.09.115

Skrzypek, M., and M. Burger. 2010. Isoflux ceramic membranesPractical experiences in dairy industry. Desalination 250:10951100. http://dx.doi.org/10.1016/j.desal.2009.09.116.

Trouvé, E., J. L. Maubois, M. Piot, M. N. Madec, J. Fauquant, A. Rouault, J. Tabard, and G. Brinkman. 1991. Rétention de différentes espèces microbiennes lors de l' épuration du lait par microfiltration en flux tangentiel. Lait 71:1-13.

Weast, R. C., M. J. Astle, and W. H. Beyer. 1988. CRC Handbook of Chemistry and Physics. 69th ed. CRC Press Inc., Boca Raton, FL.

Zulewska, J., and D. M. Barbano. 2014. The effect of linear velocity and flux on performance of ceramic graded permeability membranes when processing skim milk at $50^{\circ}$ C. J. Dairy Sci. 97:2619 2632. http://dx.doi.org/10.3168/jds.2013-7635.

Zulewska, J., M. Newbold, and D. M. Barbano. 2009. Efficiency of serum protein removal from skim milk with ceramic and polymeric membranes at 50 degrees C. J. Dairy Sci. 92:1361-1377. http:// dx.doi.org/10.3168/jds.2008-1757. 